Oxford Review of Economic Policy, Volume 27, Number 3, 2011, pp. 437-463

\title{
Why bank governance is different
}

\author{
Marco Becht, ${ }^{*}$ Patrick Bolton, ${ }^{* *}$ and Ailsa Röell ${ }^{* * *}$
}

\begin{abstract}
This paper reviews the pattern of bank failures during the financial crisis and asks whether there was a link with corporate governance. It revisits the theory of bank governance and suggests a multiconstituency approach that emphasizes the role of weak creditors. The empirical evidence suggests that, on average, banks with stronger risk officers, less independent boards, and executives with less variable remuneration incurred fewer losses. There is no evidence that institutional shareholders opposed aggressive risk-taking. The Financial Stability Board published Principles for Sound Compensation Practices in 2009, and the Basel Committee on Banking Supervision issued principles for enhancing corporate governance in 1999, 2006, and 2010. The reports have in common that shareholders retain residual control and executive pay continues to be aligned with shareholder interests. However, we argue that bank governance is different and requires more radical departures from traditional governance for non-financial firms.
\end{abstract}

Key words: banking, commercial banks, investment banks, financial intermediation, risk management, risk taking, debt overhang, deposit insurance, bailouts, governance, board composition, financial expertise, Basel principles

JEL classification: G20, G21, G24, G28, G32, G34

\section{Introduction}

The international corporate governance debate has mostly focused on: (i) weak shareholders and dominant executives in the United States, (ii) insufficiently engaged shareholders in the United Kingdom, and (iii) powerful but conflicted blockholders in most other countries. The traditional conflicts between shareholders, managers, and boards are also present in banks. Many banks, including the largest, are limited liability stock corporations. Like any other type of corporation they can be afflicted by board failure on strategy and oversight, misaligned or perverse incentives, empire building, conflicts of interest, weaknesses in internal controls, incompetence, and fraud.

*Solvay Brussels School, Université Libre de Bruxelles, ECGI, and CEPR, e-mail: mbecht@ulb.ac.be

**Columbia University, ECGI, CEPR, and NBER, e-mail: pb2208@columbia.edu

***Columbia University, ECGI, and CEPR, e-mail: ar2319@columbia.edu

We would like to thank Mathias Dewatripont, Jose Martinez, Andrea Polo, and the editors for constructive comments. Becht is grateful to Stanford Law School and the Rock Center for Corporate Governance for hosting him while working on a previous draft and to the Belgian Fonds de la Recherche Scientifique (FNRS) and the Goldschmidt Chair for Corporate Governance at the Solvay Brussels School of Economics and Management (ULB) for financial support.

doi: 10.1093/oxrep/grr024

(C) The Authors 2012. Published by Oxford University Press.

For permissions please e-mail: journals.permissions@oup.com 
But banks also have specific governance issues. The very nature of the banking business weakens the traditional corporate governance institutions of board and shareholder oversight. Banks have the ability to take on risk very quickly, in a way that is not immediately visible to directors or outside investors. A multitude of quickly evolving and technically complex trading activities need to be monitored by specialists who are in short supply. In widely held banks, shareholder oversight is expensive and often left to conflicted institutional investors and/or insufficiently qualified directors. Regulation and valuation difficulties also weaken the potential role of the market for corporate control. Blockholder conflicts may also be exacerbated in banks, as bank lending can easily be steered to pet projects. Finally, while banks are heavily regulated, they may also be subject to strong political influence, fostered by revolving-door appointments and campaign contributions to political parties.

Banks are multi-constituency organizations. Depositors and bondholders contribute almost all of a bank's capital, yet most decisions are taken by managers, boards, and shareholders. Bank executives do not have to seek permission from depositors before changing a bank's risk profile.

While depositors can 'run', in most countries they are indifferent to the bank's financial prospects because they are protected by deposit insurance or a state guarantee. During the financial crisis this guarantee was de facto extended to bondholders and other creditors, who had refused to roll over their loans. The largest, most complex, and most difficult to govern institutions were covered by an implicit 'too big to fail' guarantee. In this context, what should be the role of unprotected creditors, deposit insurers, and the state - as the ultimate provider of guarantees for protected creditors - in bank governance? Is bank regulation a complement or a substitute for corporate governance?

Empirically it has been difficult to establish a link between bank failures and corporate governance, partly because government rescues have masked the true extent of the banks' problems, and partly because so many other factors have contributed to bank failures. Even so, recent empirical research on corporate governance and the crisis confirms that bank governance is different. There is powerful evidence that executive remuneration induced risk-shifting at US investment banks, commercial banks, and insurance companies. Risk-taking at these institutions is highly correlated with short-term cash pay-outs in the form of base pay, bonuses, and share and option sales. The latest evidence also suggests that losses at banks with so-called tougher boards, that is, boards that were more independent of senior executives, have paradoxically been larger. There is, however, no direct evidence as yet that shareholders insisted on more risk-taking - but there is no evidence that they opposed it either.

The latest Basel Principles for enhancing corporate governance recognize that boards and executives have a responsibility to creditors and not just to shareholders, but do not change the fundamental power structure in banks. Shareholders continue to have the exclusive power to appoint and remove directors. To make bank governance more effective it might be necessary to experiment with deeper reforms, such as allowing for creditor representation on boards, either directly or through a representative agent, such as the deposit insurance fund. Besides helping mitigate risk-shifting, this type of representation would also facilitate the operation of bail-ins and other types of resolution requiring debt-to-equity swaps at very short notice.

The current proposals on remuneration reform have similar shortcomings. Although remuneration reform at banks was discussed at the highest level—at the G20 — with the Financial Stability Board (FSB) recommending specific implementation standards, few concrete and far-reaching proposals have been made. The emphasis is on better aligning 
remuneration with risk-taking. These reforms may move in the right direction, but only so much. Banks are allowed to develop their own policies and encouraged to make their own risk adjustments. It is doubtful that supervisors will have the competence or resources to monitor these developments. Simple rules might be preferable to idiosyncratic complexity.

Section II looks back at financial institutions that failed during the crisis and explores if there is any obvious correlation with the organizational form or specific corporate governance characteristics of these firms. Section III reviews why bank governance differs from the governance of non-financial institutions. Section IV reviews the existing empirical evidence, particularly on executive compensation and boards. Section V reviews the main reform proposals. Section VI concludes.

\section{Bank failures during the financial crisis}

The financial crisis first manifested itself in early 2007. The Federal Reserve Bank of St Louis marks the beginning of the crisis with the filing for Chapter 11 bankruptcy protection of the New Century Financial Corporation, and the announcement by the Federal Home Loan Mortgage Corporation (Freddie Mac) that it would no longer buy the most risky subprime mortgages (27 February 2007). Others, like the cable television network CNN, set the initial marker to 7 February 2007, when HSBC announced substantial losses linked to the US subprime market. A string of failures in the United States and Europe followed, including the nationalization of Northern Rock in the United Kingdom, the bailout of Bear Stearns by the US Federal Reserve, the bankruptcy of Countrywide Financial in California, and the government rescues of IKB in Germany and Roskilde Bank in Denmark. Events accelerated in September 2008 with the US government taking over Freddie Mac and Fannie Mae, the bankruptcy filing of Lehman Brothers, and the failure of AIG. Following these momentous events, banks started failing on a daily basis and there was widespread panic in global equity and credit markets.

The authorities on both sides of the Atlantic reacted by launching unprecedented assistance programmes. In the US the Troubled Asset Relief Programme (TARP) made direct investments totalling $\$ 204.7$ billion in 739 banks. These investments went to the largest troubled banks to prevent them from failing and to the strongest smaller banks to prop up their capital and stimulate lending. The federal government also assisted credit unions (\$57 billion), and Fannie Mae and Freddie Mac (\$110.6 billion). The largest single recipients of aid were AIG ( $\$ 127.4$ billion), Citibank ( $\$ 50$ billion), and Bank of America ( $\$ 35$ billion). Despite these efforts the total number of failures among Federal Deposit Insurance Corporation (FDIC) insured banks from 2007 to 2010 amounted to 325, at a cost to the deposit insurance fund of $\$ 79.3$ billion (Tables 1, 2).

In the EU most member states provided general guarantees for the whole banking system as well as support for the weakest banks, through capital injections, guarantees on bank liabilities, impaired asset relief, and funding support. State aid to the banking system in each member state had to be notified to and approved by the European Commission's Directorate General for Competition. Most schemes were approved but often tied to corporate restructuring requirements or other conditions. In contrast to TARP, most of the aid did not take the form of capital injections (capital purchases), but guarantees. The general view was that banks were not insolvent but merely suffering from a liquidity crisis. The hope was that the guarantees and other liquidity-supporting measures would ensure that the guarantees would never result in actual losses for the state. 


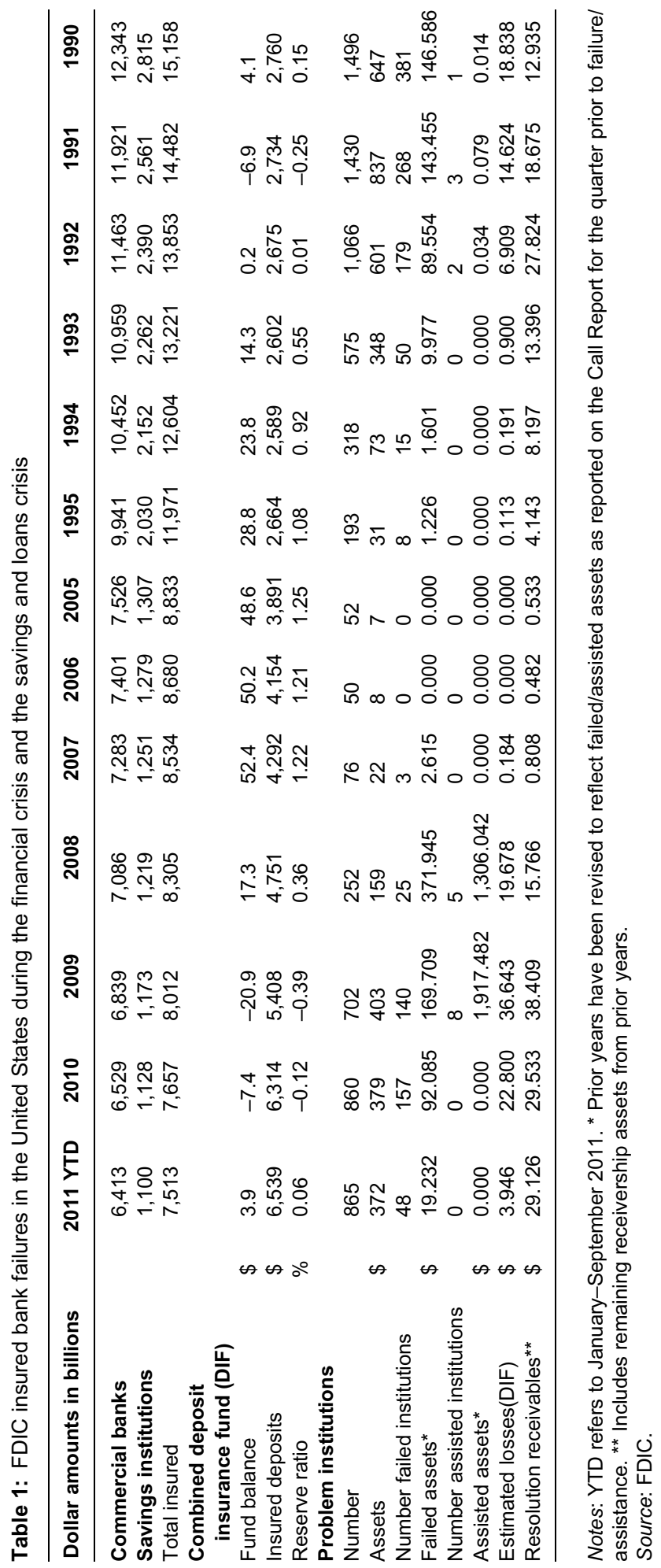


Table 2: Investments under the TARP capital purchase programme in excess of $\$ 1$ billion

\begin{tabular}{|c|c|c|c|}
\hline Name of institution & State & Investment amount & Repayment by January 2011 \\
\hline Citigroup Inc. & NY & $\$ 25.000 .000 .000$ & Full \\
\hline JPMorgan Chase \& Co. & NY & $\$ 25.000 .000 .000$ & Full \\
\hline Wells Fargo \& Company & CA & $\$ 25.000 .000 .000$ & Full \\
\hline Bank of America Corporation & NC & $\$ 15.000 .000 .000$ & Full \\
\hline The Goldman Sachs Group, Inc. & NY & $\$ 10.000 .000 .000$ & Full \\
\hline Morgan Stanley & NY & $\$ 10.000 .000 .000$ & Full \\
\hline Bank of America Corporation & NC & $\$ 10.000 .000 .000$ & Full \\
\hline The PNC Financial Services Group Inc. & PA & $\$ 7.579 .200 .000$ & Full \\
\hline US Bancorp & $\mathrm{MN}$ & $\$ 6.599 .000 .000$ & Full \\
\hline Capital One Financial Corporation & VA & $\$ 3.555 .199 .000$ & Full \\
\hline SunTrust Banks, Inc. & GA & $\$ 3.500 .000 .000$ & No \\
\hline Regions Financial Corporation & $\mathrm{AL}$ & $\$ 3.500 .000 .000$ & No \\
\hline Fifth Third Bancorp & $\mathrm{OH}$ & $\$ 3.408 .000 .000$ & No \\
\hline Hartford Financial Services Group, Inc. & CT & $\$ 3.400 .000 .000$ & Full \\
\hline American Express Company & NY & $\$ 3.388 .890 .000$ & Full \\
\hline BB\&T Corp. & NC & $\$ 3.133 .640 .000$ & Full \\
\hline The Bank of New York Mellon Corporation & NY & $\$ 3.000 .000 .000$ & Full \\
\hline KeyCorp & $\mathrm{OH}$ & $\$ 2.500 .000 .000$ & No \\
\hline CIT Group Inc. & NY & $\$ 2.330 .000 .000$ & No \\
\hline Comerica Inc. & $\mathrm{TX}$ & $\$ 2.250 .000 .000$ & Full \\
\hline State Street Corporation & MA & $\$ 2.000 .000 .000$ & Full \\
\hline Marshall \& Ilsley Corporation & WI & $\$ 1.715 .000 .000$ & No \\
\hline Northern Trust Corporation & IL & $\$ 1.576 .000 .000$ & Full \\
\hline Zions Bancorporation & UT & $\$ 1.400 .000 .000$ & No \\
\hline Huntington Bancshares & $\mathrm{OH}$ & $\$ 1.398 .071 .000$ & Full \\
\hline SunTrust Banks, Inc. & GA & $\$ 1.350 .000 .000$ & No \\
\hline Discover Financial Services & IL & $\$ 1.224 .558 .000$ & Full \\
\hline
\end{tabular}

Note: In total there were 739 investment recipients.

Source: TARP transactions report for the period ending 19 January 2011.

In the case of Belgium, the Netherlands, and the United Kingdom, the total effective aid granted by July 2009 exceeded 20 per cent of GDP, and in the case of Ireland, 229 per cent (Table 3). In 2010 it became evident that the largest Irish banks were not suffering a liquidity crisis but were actually insolvent. Their recapitalization and guarantee-related losses caused a sovereign debt crisis, resulting in a bailout from the European Union (EU) and the International Monetary Fund (IMF). The Irish banks had previously passed EU-wide stress tests, casting serious doubts on the methodology employed, as well as the resolution procedures employed.

According to the European Commission's data, relatively few banks had received specific assistance between the beginning of the crisis and the end of October 2010, with the largest number of individual aid cases found in Germany, followed by Denmark, the UK, Ireland, and Belgium (Table 4). ${ }^{1}$ Bulgaria, the Czech Republic, Romania, and Slovakia did not implement any assistance programmes (Table 3).

\footnotetext{
${ }^{1}$ The table does not report state aid to the financial sector of European Economic Area (EEA) members Iceland, Norway, and Liechtenstein since this is monitored by the European Free Trade Association (EFTA) and not the European Commission. An investigation into the aid granted for the transformation of the failed Icelandic banks Glitnir, Kaupthing, and Landsbanki into successor banks Islandsbanki, Arion, and NBI (Landsbankinn) was only launched in December 2010.
} 
Table 3: State aid to European banks during the crisis as a percentage of GDP

\begin{tabular}{|c|c|c|c|c|c|c|}
\hline Country & $\begin{array}{c}\text { Capital } \\
\text { injections }\end{array}$ & $\begin{array}{c}\text { Guarantees } \\
\text { on bank } \\
\text { liabilities }\end{array}$ & $\begin{array}{c}\text { Relief of } \\
\text { impaired } \\
\text { assets }\end{array}$ & $\begin{array}{l}\text { Liquidity and } \\
\text { bank funding } \\
\text { support }\end{array}$ & $\begin{array}{c}\text { Total effective } \\
\text { for all } \\
\text { measures }\end{array}$ & $\begin{array}{l}\text { Deposit guarantee } \\
\text { scheme (in euro, } \\
\text { unless otherwise } \\
\text { indicated) }\end{array}$ \\
\hline Austria & 1.7 & 5.1 & 0.4 & 1.5 & 8.7 & $100 \%$ \\
\hline Belgium & 6.1 & 16.3 & 4.2 & NR & 26.7 & 100,000 \\
\hline Bulgaria & 0 & 0 & 0 & 0 & 0 & 50,000 \\
\hline Cyprus & 0 & 0 & 0 & 0 & 0 & 100,000 \\
\hline Czech Republic & 0 & 0 & 0 & 0 & 0 & 50,000 \\
\hline Denmark & 0.3 & 0 & 0 & 0.3 & 0.5 & $100 \%$ \\
\hline Estonia & 0 & 0 & 0 & 0 & 0 & 50,000 \\
\hline Finland & 0 & 0 & 0 & 0 & 0 & 50,000 \\
\hline France & 0.8 & 4.5 & 0.2 & 0 & 5.6 & 70,000 \\
\hline Germany & 1.6 & 7.1 & 0.4 & 0 & 9.1 & $100 \%$ \\
\hline Greece & 1.5 & 1.2 & 0 & 1.8 & 4.6 & 100,000 \\
\hline Hungary & 0.1 & 0 & 0 & 2.6 & 2.7 & $100 \%$ \\
\hline Ireland & 4.2 & 225.2 & 0 & 0 & 229.4 & $100 \%$ \\
\hline Italy & 0 & 0 & 0 & 0 & 0 & $\sim 103,000$ \\
\hline Latvia & 1.4 & 2.8 & 0 & 4.7 & 8.9 & 50,000 \\
\hline Lithuania & 0 & 0 & 0 & 0 & 0 & 100,000 \\
\hline Luxembourg & 7.9 & NR & 0 & 0.9 & 8.8 & 10,000 \\
\hline Malta & 0 & 0 & 0 & 0 & 0 & 100,000 \\
\hline The Netherlands & 6.4 & 7.7 & 3.9 & 7.5 & 25.4 & 100,000 \\
\hline Poland & 0 & 0 & 0 & 0 & 0 & 50,000 \\
\hline Portugal & 0 & 3.3 & 0 & 0 & 3.3 & 100,000 \\
\hline Romania & 0 & 0 & 0 & 0 & 0 & 50,000 \\
\hline Slovakia & 0 & 0 & 0 & 0 & 0 & $100 \%$ \\
\hline Slovenia & 0.4 & 0 & 0 & 0 & 0.4 & $100 \%$ \\
\hline Spain & 0 & 3.2 & 0 & 1.8 & 5 & 100,000 \\
\hline Sweden & 0.2 & 8.8 & 0 & 0 & 8.9 & 50,000 \\
\hline United Kingdom & 2.6 & 9.5 & 0 & 14.7 & 26.8 & $50,000^{* *}$ \\
\hline
\end{tabular}

Notes: NR indicates that the amount was not reported by the member state in its reply to the EFC questionnaire. ** The minimum level is $£ 50,000$ and in no event less than $€ 50,000$. Data from Commission Services. Effective figures are provisional and subject to cross-checking with member states, cut-off date: mid-May. Approved measures, cut-off date: 17 July 2009.

Source: European Commission, DG Competition's review of guarantee and recapitalization schemes in the financial sector in the current crisis, 7 August 2009; http://ec.europa.eu/competition/state_aid/legislation/ review_of_schemes_en.pdf (Annex 2, p. 13).

The crisis resolution mechanisms in the United States and the European Union proved to be inadequate. In the United States the FDIC handled smaller bank failures, including the sale of Washington Mutual to JPMorgan, efficiently and effectively. However, the FDIC was unable (or not allowed) to deal with the largest cases, such as Citibank. The insurance giant AIG was outside the FDIC's competence, as well as the shadow banking sector. In Europe many member states found themselves incapable of implementing swift resolution. Shareholders in the otherwise bankrupt Fortis Holding and Hypo Real Estate took the Belgian and the German governments to court, arguing that their rights had been violated during the rescues. The Iceland rescue revealed the subtle difference between subsidiaries and branches. Lehman Brothers creditors and staff in London were surprised to learn that all cash balances in London had been transferred to New York the night before the Chapter 11 filing. The UK was fortunate to have updated its legal toolbox after the run on Northern Rock. Indeed, regulation and bank governance had generally not kept up with the growing integration of the European and transatlantic financial systems. 
Table 4: European banks receiving specific state aid, 2008-10

\begin{tabular}{|c|c|c|}
\hline Country & Institution receiving aid 2008-10 & Note \\
\hline Austria & Bank für Arbeit und Wirtschaft (BAWAG AG) & $\begin{array}{l}\text { Bailed out first in } 2005 \text { when bank was } \\
\text { Union owned; bought by private equity } \\
\text { fund in } 2006\end{array}$ \\
\hline Austria & Hypo Group Alpe Adria (HGAA) & $\begin{array}{l}\text { Acquired by Bayerische Landesbank from } \\
\text { State of Kärnten }\end{array}$ \\
\hline Austria & Hypo Tirol Bank & $\begin{array}{l}\text { Bank owned by state of Tirol that guarantees } \\
\text { capital issuance }\end{array}$ \\
\hline Belgium & KBC Group & Controlled by private outside blockholders \\
\hline Belgium & Fortis & Restructured after partial sale \\
\hline Belgium & Dexia & $\begin{array}{l}\text { Franco-Belgian group with public-sector } \\
\text { clients; restructured }\end{array}$ \\
\hline Belgium & Ethias & State controlled cooperative \\
\hline Denmark & Fionia Bank & $\begin{array}{l}\text { Taken over by the Danish Financial Stability } \\
\text { Company (FSC) and sold on }\end{array}$ \\
\hline Denmark & Roskilde Bank & $\begin{array}{l}\text { Taken over by National Bank and Private } \\
\text { Contingency Association; assets transferred } \\
\text { to FSC }\end{array}$ \\
\hline Denmark & EBH Bank & Taken over by FSC \\
\hline Denmark & Løkken Sparekasse & $\begin{array}{l}\text { Taken over by FSC and merged with EBH } \\
\text { Bank }\end{array}$ \\
\hline Denmark & Eik Bank & Taken over by FSC \\
\hline Denmark & Gudme Raaschou Bank & Taken over by FSC \\
\hline France & Caisse d'Épargne / Banque Populaire & Merger between the two banks \\
\hline Germany & Westdeutsche Landesbank & Landesbank \\
\hline Germany & Landesbank Baden Württemberg & Landesbank \\
\hline Germany & Bayerische Landesbank & Landesbank \\
\hline Germany & Hypo Real Estate & $\begin{array}{l}\text { Had acquired state-controlled Depfa } \\
\text { mortgage lender }\end{array}$ \\
\hline Germany & HSH Nordbank AG & Landesbank \\
\hline Germany & Commerzbank & $\begin{array}{l}\text { Widely held; acquired Dresdner Bank from } \\
\text { Allianz with significant US exposure }\end{array}$ \\
\hline Germany & $\mathrm{IKB}$ & Subsidiary of state controlled KfW \\
\hline Ireland & EBS Building Society & Mutual society without shareholders \\
\hline Ireland & Anglo-Irish Bank & Widely held bank \\
\hline Ireland & Allied Irish Bank & Widely held bank \\
\hline Ireland & Bank of Ireland & Widely held bank \\
\hline Ireland & Irish Nationwide Building Society & Mutual society without shareholders \\
\hline Latvia & Parex Bank & Nationalization \\
\hline The Netherlands & ING & $\begin{array}{l}\text { Widely held bank with significant US } \\
\text { exposure }\end{array}$ \\
\hline The Netherlands & Aegon & $\begin{array}{l}\text { Widely held insurance company with } \\
\text { significant US exposure }\end{array}$ \\
\hline Spain & Caja Castilla La Mancha & Non-listed savings bank \\
\hline Sweden & Carnegie Bank & $\begin{array}{l}\text { Listed investment bank that was } \\
\text { nationalized in } 2009\end{array}$ \\
\hline United Kingdom & Northern Rock Plc & $\begin{array}{l}\text { Mostly online bank that failed after a bank } \\
\text { run }\end{array}$ \\
\hline United Kingdom & Lloyds Banking Group & Widely held bank \\
\hline United Kingdom & Bradford and Bingley & Widely held bank after demutualization \\
\hline United Kingdom & Dunfermline Building Society & Mutual society without shareholders \\
\hline United Kingdom & Royal Bank of Scotland & Widely held bank \\
\hline
\end{tabular}

Source: European Commission DG Competition, State Aid Database. 
The attitude of governments towards rescued banks was similar across countries. The new government equity holdings were administered in a passive way and governments refused to get involved in the governance of individual banks as a majority shareholder (with the exception of general restrictions on remuneration and pay-out policies imposed during the recapitalization). The role of the government, or bondholders after a bail-in, as a shareholder in a rescued bank is an important issue to explore but is beyond the scope of this paper.

Is there a link between bank governance, leverage, risk-taking, and bank failure? The empirical answer is not self-evident. The list of institutions that failed, or only survived because they received assistance from the state, is heterogeneous. It involves real estate investment trusts, insurance companies, savings banks, commercial banks, investment banks, and banking conglomerates. Most failed institutions were organized as stock corporations, but some were mutual banks or credit unions. Most stock corporations were widely held, but some had large outside shareholders. In Europe, many of the failed institutions were owned and/or controlled by the state. In some countries almost the entire banking sector collapsed, in other countries (Canada is a notable example) no banks failed at all.

The sources of losses and the reasons for failure also vary across countries and institutions. Among the worst affected were those that participated directly in the origination and/or distribution of asset-backed securities and derivative products. Banks that invested heavily in these securities also suffered; these included the US credit unions and many European banks. Several banks had made or were in the process of making corporate acquisitions, at what turned out to be disastrously high prices. Northern Rock in the UK had expanded aggressively by reducing staff in branches and taking deposits through the internet. In an uncertain environment a computer problem on the weekend and the photo of a queue outside an understaffed branch caused a bank run. Regular mortgage lenders in Denmark, Ireland, Spain, the United Kingdom, and the United States were badly affected by the local fall in house prices. Many institutions were simply caught in the general liquidity squeeze and the oncoming recession. In short, most failures were due to a combination of factors.

\section{What is different about bank governance: the theory}

The nature of banks' activities presents unique challenges that need to be addressed by their governance mechanisms. This section explores some of the specificities of financial intermediation and their implications for corporate governance.

A crucial function performed by commercial banks - and, increasingly in recent years, by the shadow banking sector as well-is maturity transformation: using the very liquid shortterm demand deposits and wholesale funds desired by investors to invest in risky, illiquid projects with a distant pay-off horizon. The role played by banks in this process involves (i) reducing risk by putting together a diversified loan and investment portfolio, and (ii) bearing the cost of generating the information needed to select and monitor the projects in which money is invested. As formalized in the seminal analysis of Diamond and Dybvig (1983), the maturity mismatch leaves banks open to liquidity risk in the form of bank runs: even when the bank's underlying business is fundamentally sound, mass withdrawal of short-term funding may necessitate premature liquidation of long-term investment projects. Deposit insurance is a means to discourage such concerted withdrawals of deposits and short-term funding from banks that would otherwise be solvent. 
This begs the question of why financial intermediaries do not use more long-term funding to mitigate the maturity mismatch problem. The root cause of the problem lies in the very nature of the business, which is fast moving, risky, and opaque, so that it is very difficult to ensure through bond covenants or other means of monitoring that creditors' money is not put at undue risk. Banks are in the business of taking risks; they can take on risk quickly and easily; they can mask, to some extent, how much risk they take. Their portfolios are often illiquid and hard-to-value, their positions shift rapidly, and their assets and liabilities can be extremely complex. This compromises the availability of long-term funding, be it debt or equity.

Thus long-run debt is much less commonly used to fund operations than short-run debt. Shareholder-creditor conflicts are potentially important and risk-shifting, in particular, is a major concern, especially in bad times when the going-concern value of the bank is low and its management is tempted to 'gamble for resurrection'; a numerical example is given in Appendix I, while a real-world case of risk-shifting is that of subprime lender New Century Financial, which significantly increased its exposure to risk as its financial situation deteriorated, as documented by Landier et al. (2010). Normally short-term funding curtails risk-shifting because funding quickly dries up when a financial institution reaches the point of insolvency. But with government deposit insurance, this disciplinary effect is absent and needs to be replaced by regulatory monitoring and intervention; a hard-won lesson from the savings and loan (S\&L) crisis of the late 1980s, when troubled S\&Ls gambled heavily by investing in junk bonds, which hugely increased the ultimate cost to taxpayers. Capital requirements for FDIC-insured institutions were tightened considerably in the wake of that crisis, but attention to the problem waned over time (Morgenson and Rosner, 2011).

The same reason - balance sheet opacity - that pushes banks to rely disproportionately on short-term debt, also induces them to minimize their reliance on outside equity. The tax advantages of debt finance and the effective government subsidy to the use of debt - both via explicit deposit insurance and in the form of less clearly delineated implicit guarantees - are added reasons why banks economize on equity capital even in normal times. In bad times, shareholder-bondholder conflicts mean that firms will not or cannot obtain equity capital altogether - a problem known as debt overhang. For example, at the helm at Lehman Bros, Dick Fuld had ample opportunity to raise additional equity in the year before its demise, but dithered until June 2008, raising too little capital, too late (see Ross Sorkin (2009) for a detailed account). In Appendix II we provide a numerical example of debt overhang that illustrates how a firm that approaches insolvency will be unwilling to shore up its capital, and, if the situation worsens any further, unable to do so.

What this means for corporate governance is that not only shareholders but also depositors, other creditors, transaction counterparties, and, in most countries, also the taxpayers, are at risk from banks' activities. It follows that mechanisms should be in place to protect not just the interests of shareholders (the primary focus of much of the literature on corporate governance, surveyed in Becht et al. (2007)) but also the interests of these other constituencies. Proposals to address these concerns by either empowering stakeholders or limiting their exposure include enhanced capital adequacy regulations, intervention powers for deposit insurers, the proposed 'Volcker rule' that limits proprietary trading by depositinsured institutions, as well as calls to reduce the size of banking behemoths that are 'too big to fail', possibly through the reinstatement of the Glass-Steagall separation of investment and commercial banking. 


\section{(i) Compensation in banks}

There are important caveats to the standard model of incentive compensation when applied to the financial services industry. The first caveat is the absence of leverage. The standard theory refers to an all-equity firm with no debtholders, a feature it shares with most other compensation theories that are normally discussed in corporate governance. But banks are highly leveraged organizations. When managers are rewarded with stock grants they have a conflict of interest with debtholders, just like any other bank shareholders. The fear of loss of human capital or reputation might make managers less inclined to take risks than ordinary shareholders. But the combination of leverage with the other caveats discussed below makes it more likely that bank executives have an incentive to take more risks than is desirable.

A second caveat to the standard theory is the absence of endogenous choice of risk or volatility of earnings. In standard models there is no link between incentives and risk-taking, a central feature of a reward model for banks.

The third caveat is the assumption of market completeness, which precludes asset bubbles. House price bubbles have been a major feature of the crisis in the United States, the United Kingdom, Ireland, Spain, Denmark, and some parts of Eastern Europe. A policy relevant theory of pay in banks should therefore allow for bubbles. Bolton et al. (2006) introduce a model of financial markets that relies on the idea that investors have fundamentally different sets of opinions, making them disagree about the fundamental value of a company, or another type of asset. Bubbles can develop because optimists will buy stocks and short sales constraints will prevent the pessimists from betting against that stock. The stock (or house, or mortgage-backed security) is held most often by optimists. The bubble is generated by the idea that an optimist hopes to be able to sell to someone who is even more optimistic than him- or herself. Investors do not look at fundamental value but at how opinions evolve over time, taking into account what other investors will think in the future. The bubble bursts when the most optimistic optimists are unable to find a buyer.

Allowing for the endogenous choice of volatility or risk and putting together bubbles with volatility choice easily generates incentives towards excess risk-taking, even for an all-equity firm. Investors try to maximize the fundamental value of the firm, but they also want to maximize the speculative option value, the option to be able to sell to a more optimistic investor. Since option value is strictly increasing with volatility, shareholders and managers owning shares have an incentive to increase volatility.

\section{(ii) Rewarding beta}

The problem of rewarding bankers is similar to that debated in the mutual fund literature, where there has been a long-time quest for rewarding alpha rather than beta, the sensitivity of fund returns with respect to the relevant market. Mutual fund managers should not be rewarded for market movements, but for their 'contribution to alpha', the intrinsic performance of the fund. In practice, bank CEOs are awarded with 'at the money' options. These options are not indexed to any measure of a market portfolio, or some other benchmark. Without correcting for beta, very large and positive stock price returns might be purely driven by very high loading on beta. In a boom phase a high beta bank will, by definition, outperform the market. The CEO will have an incentive to increase the sensitivity of the bank's performance to the market, which is not very difficult. The CEO will be managing the bank for a relatively short period of time and will retire or vest his or her options, or stock, before the boom is over. 
The situation is even worse with bonuses tied to absolute performance. Bonuses are pure cash payouts. Restricted stock, or options that convert to restricted stock, are a contribution to the bank's capital, at least during the time they cannot be sold. We now have solid empirical evidence that there was a strong link between total cash payouts for senior executives and risk-taking at US banks in the run-up to the crisis.

Are there alternative remuneration schemes that align executive incentives more effectively with creditors and deposit insurers? Bolton et al. (2010) develop a model that proposes to link executive compensation to leverage. In the model, the shareholders of a leveraged institution will provide CEOs with monetary incentives to take excessive risk. To avoid this problem, the authors propose to link executive pay not just to stock price performance, but also to a measure of default risk. In particular, they propose to link pay to the credit default swap (CDS) spread of the bank relative to the average CDS spread for a basket of banks. To the extent that the CDS spread deviates, being larger or smaller than the average, the CEO is rewarded or penalized.

\section{Bank governance is different: the evidence}

Bank governance is different in theory. Is it also different in practice? We review the latest empirical studies that explore the link between corporate governance characteristics of financial institutions and how they fared during the financial crisis. We look at the 'usual suspects' in corporate governance: boards and ownership concentration. We then turn to executive pay and internal controls.

\section{(i) Boards}

Post-Enron reforms in the United States imposed substantial changes on corporate boards. In 2003 the New York Stock Exchange (NYSE) and NASDAQ altered their listing rules, requiring domestic US issuers to appoint a majority of independent directors to the board and to establish audit, nominating, and compensation committees composed entirely of independent directors by the end of 2004. Outside the United States similar, though nonbinding, recommendations were made through corporate governance codes. There were also recommendations to reduce board size and appoint directors with enough free time. The Basel recommendations on bank governance issued in 2006 endorsed these measures but also emphasized qualifications: 'Board members should be qualified for their positions, have a clear understanding of their role in corporate governance and be able to exercise sound judgement about the affairs of the bank (Principle 1).' Basel also extended the concept of independence to mean independent from management and from large shareholders, including the state.

How did banks respond? A recent study of international bank boards (Ferreira et al., 2010) confirms that the average US bank holding company board became smaller, and had more independent, less busy, and somewhat less competent directors (Table 5). US banks always exceeded the NYSE independence requirement: The percentage of independent directors was already 51 per cent in 2000 but increased further to 67 per cent in 2007 . The average board size decreased from 15 to 11.6 members. The average bank board outside the United States did not adopt the US reforms. The number of independent directors was consistently smaller than 50 per cent, boards were larger than in the US and populated by directors with more 
Table 5: Evolution of bank board composition, 2000-8

\begin{tabular}{|c|c|c|c|c|}
\hline Year & Mean board size & $\begin{array}{l}\text { Independent directors } \\
\text { as } \% \text { of all directors }\end{array}$ & $\begin{array}{l}\text { Mean } \% \text { of outside } \\
\text { directors with previous } \\
\text { banking experience }\end{array}$ & $\begin{array}{l}\text { Mean of average } \\
\text { number of board } \\
\text { appointments of } \\
\text { outside directors }\end{array}$ \\
\hline \multicolumn{5}{|c|}{ Panel 1 : All banks $(\mathrm{N}=718)$} \\
\hline 2000 & 15.0 & 41 & 29 & 3.6 \\
\hline 2001 & 14.8 & 44 & 28 & 3.5 \\
\hline 2002 & 14.4 & 49 & 28 & 3.6 \\
\hline 2003 & 12.4 & 62 & 23 & 3.0 \\
\hline 2004 & 11.9 & 66 & 21 & 2.9 \\
\hline 2005 & 11.7 & 67 & 21 & 2.9 \\
\hline 2006 & 11.6 & 67 & 21 & 2.9 \\
\hline 2007 & 11.7 & 65 & 23 & 2.9 \\
\hline 2008 & 11.7 & 63 & 24 & 2.9 \\
\hline \multicolumn{5}{|c|}{ Panel 2 : United States banks $(N=500)$} \\
\hline 2000 & 13.7 & 51 & 21 & 2,8 \\
\hline 2001 & 13.7 & 55 & 22 & 2,8 \\
\hline 2002 & 13.1 & 62 & 22 & 2,8 \\
\hline 2003 & 11.4 & 69 & 20 & 2,5 \\
\hline 2004 & 11.2 & 72 & 18 & 2,5 \\
\hline 2005 & 10.8 & 73 & 17 & 2,5 \\
\hline 2006 & 10.7 & 74 & 18 & 2,5 \\
\hline 2007 & 10.7 & 74 & 18 & 2,5 \\
\hline 2008 & 10.6 & 73 & 20 & 2,5 \\
\hline \multicolumn{5}{|c|}{ Panel 3 : Non-US banks $(\mathrm{N}=218)$} \\
\hline 2000 & 17.0 & 25 & 41 & 4.9 \\
\hline 2001 & 16.6 & 27 & 37 & 4.6 \\
\hline 2002 & 16.4 & 30 & 37 & 4.8 \\
\hline 2003 & 16.1 & 34 & 36 & 4.8 \\
\hline 2004 & 15.4 & 40 & 35 & 4.7 \\
\hline 2005 & 15.5 & 39 & 36 & 4.6 \\
\hline 2006 & 15.3 & 40 & 36 & 4.6 \\
\hline 2007 & 15.2 & 36 & 37 & 4.4 \\
\hline 2008 & 15.0 & 35 & 38 & 4.0 \\
\hline
\end{tabular}

Source: Ferreira et al. (2010).

outside appointments. However, a larger percentage of directors had previous banking experience (36 per cent compared to 18 per cent in the United States in 2006).

Looking across countries, board independence did not prevent failure in the US, the UK, and Ireland, but at the same time it did not undermine stability in Canada and India (Ferreira et al., 2010, Table III). Independence does, however, correlate with losses at the bank level. Erkens et al. (2010) regress stock performance and write-downs during the crisis on the percentage of independent directors across a heterogeneous sample of 296 banks, $^{2}$ finding that independence was associated with greater shareholder losses, even when controlling for other factors, such as institutional ownership. ${ }^{3}$ Beltratti and Stulz (2011) only look at deposittaking banks. They find that banks with more shareholder-friendly boards, measured by

\footnotetext{
${ }^{2}$ The sample is skewed toward the US (125 banks); larger countries include Germany (19 banks), Italy (19), the UK (17), and Switzerland (15).

${ }^{3}$ The study reports more independence for non-US boards than Ferreira et al. (2010).
} 
aggregated scores for meeting minimum standards for 'good-governance' attributes relating to board independence, composition of committees, size, transparency, and conduct, as defined by Institutional Shareholder Services, fared distinctly worse during the crisis. The sample is more comparable across banks, but smaller (98 large deposit-takers), so country effects outside the US are poorly identified.

Indeed, cross-country studies control imperfectly for interactions between board independence and local institutions, potentially biasing the results. Minton et al. (2010) avoid this problem by studying a large sample of US commercial banks ( 75 per cent), savings and loans associations ( $\sim 23$ per cent), and investment banks ( 2 per cent) from 2003 to 2008. They confirm that board independence is associated with poor stock performance and decreases in market-to-book ratios during the crisis. However, for the pre-crisis period (2003-6) board independence has an insignificant impact on risk-taking in large commercial banks. Interestingly, there is a strong positive relation with the percentage of independent financial experts on the board: 'this result is ... more generally consistent with a more financially knowledgeable board having a better understanding of more complex investments and potentially encouraging bank management to increase their risk taking' (p. 24). ${ }^{4}$ But direction of causality could plausibly be the reverse: perhaps banks that wanted to take more risk appointed independent directors with more financial expertise (Mehran et al., 2011).

Evidence from Europe suggests that the boards of failed institutions did not understand what some employees of the bank were doing. In Germany and Spain board incompetence correlates very strongly with losses incurred during the crisis at state-controlled Landesbanken (Hau and Thum, 2009, see Figure 1) and state- or church-dominated Cajas (Cuñat and Garicano, 2010). These studies seem to contradict the US findings.

The contradiction illustrates the limitations of regression analysis as a basis for policy recommendations, particularly across countries. The regression analysis from Germany is consistent with the latest interview 'evidence': the underpaid and insufficiently qualified bankers at IKB and the Landesbanken were no match for highly motivated bond salesmen from London and New York (Lewis, 2011). However, forensic analysis by Ernst \& Young into the demise of Sachsen LB on behalf of its owner, the Land, squarely blamed the management: the board had not been informed about the deteriorating situation of the bank's Irish conduits. Board members never had a chance to show their (in)competence. ${ }^{5}$ In contrast, the board and the management of New Century Financial appear to have acted quite deliberately. A number of directors and executives told the bankruptcy examiner that they did not focus 'on whether borrowers could meet their obligations under the term of the mortgage', but 'whether the loans New Century originated could be initially sold or securitized in the secondary market' (Missal, 2008, p. 4). In sum, board competence appears to be a necessary condition for avoiding Landesbanken and Cajas type problems, but financially experienced boards must also be given the right incentives to dissuade them from taking excessive risks.

\footnotetext{
${ }^{4}$ Fernandes and Fich (2009) present contradictory evidence; they find that the likelihood of failure and/or of receiving bailout funds was smaller when banks had boards with more financial expertise. Minton et al. (2010, p. 6) conjecture that differences in variable definition and/or sample composition might explain the inconsistency.

${ }^{5}$ Christian Geinitz, 'Gutachter kritisieren Vorstand scharf', FAZ.net, 11 March 2008.
} 
Figure 1: Directors' financial competence and losses for German banks

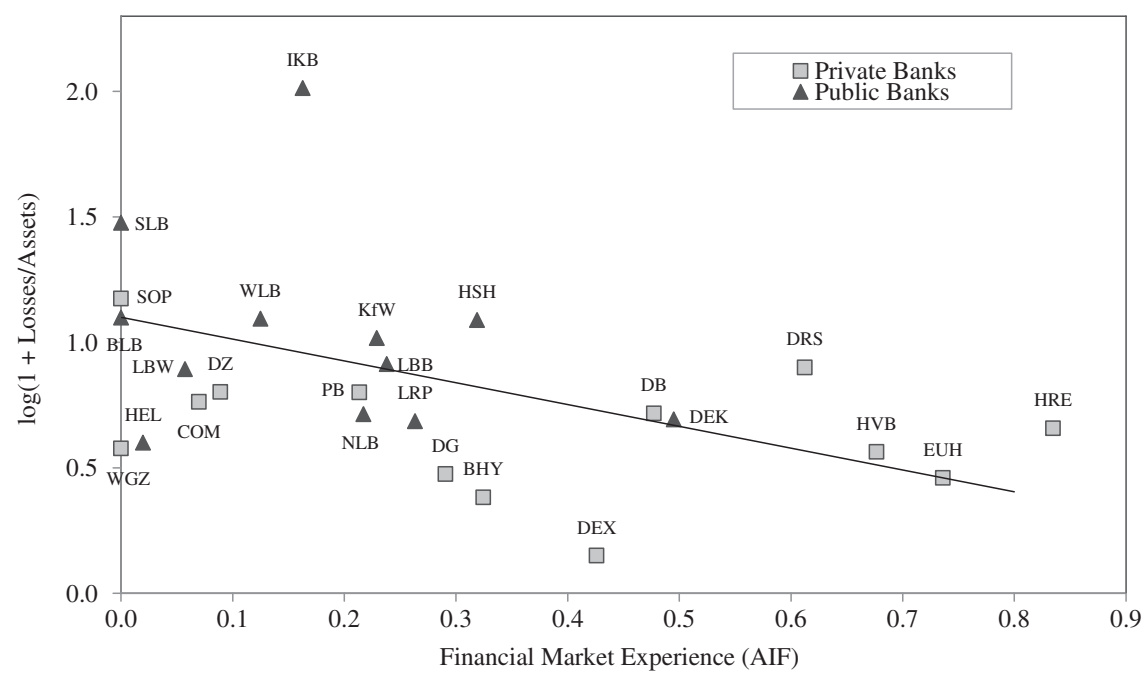

Notes: BHY: Berlin-Hannoversche Hypothekenbank; BLB: Bayern LB; COM: Commerzbank; DB: Deutsche Bank; DEK: Dekabank; DEX: Dexia Kommunalbank Deutschland; DG: Deutsche Genossenschafts-Hypothekenbank; DRS: Dresdner Bank; DZ: DZ Bank; EUH: Eurohypo; HEL: Helaba; HRE: Hypos Real Estate; HSH: HSH Nordbank; HVB: HVB Group; KfW: KfW Bankengruppe; LBB: Landesbank Berlin; LBW: LBBW; LRP: LRPLandesbank RheinlandPfalz; NLB: Nord LB; PB: Postbank; SLB: Sachsen LB; SOP: Sal. Oppenheim Jr \& Cie; WGZ: WGZ Bank AG Westdeutsche Genossenschafts-Zentralbank; WLB: WestLB.

Source: Hau and Thum (2009).

\section{(ii) Ownership and control}

Did concentrated shareholders encourage managers to take on more risk and/or more leverage? We review the available evidence on institutional ownership, blockholders (including state ownership), and ownerless banks. There is one piece of convincing evidence that institutional shareholders did not oppose risk-taking, but no direct evidence that they encouraged it. Previous work suggesting that blockholder ownership outside the United States was associated with bank instability has been called into question by the crisis.

The available evidence is indirect and comes from studies that correlate the percentage of institutional ownership with risk-taking and/or shareholder returns, while controlling for other governance variables. Two studies (Beltratti and Stulz, 2010; Erkens et al., 2010) find a positive relationship. The findings are consistent with the theories we discussed in the earlier section, but not conclusive.

In the US there is an active debate about how much influence institutional shareholders have on corporate policy. Institutional activism through shareholder proposals is notoriously ineffective (Karpoff, 2001). Hedge-fund activism is more effective (Brav et al., 2009) but in 2000-8 was rarely targeted at banks (Becht et al., 2011). In the United Kingdom, institutional shareholders can have substantial influence on directors and boards, but such influence is often exercised in private (Becht et al., 2008). There is also evidence from parliamentary hearings on the absence of formal shareholder dissent at UK banks. This includes advisory votes on executive pay that were phased in during the pre-crisis years and non-existent in the United States (Table 6). If there had been private dissent it is likely that institutional 


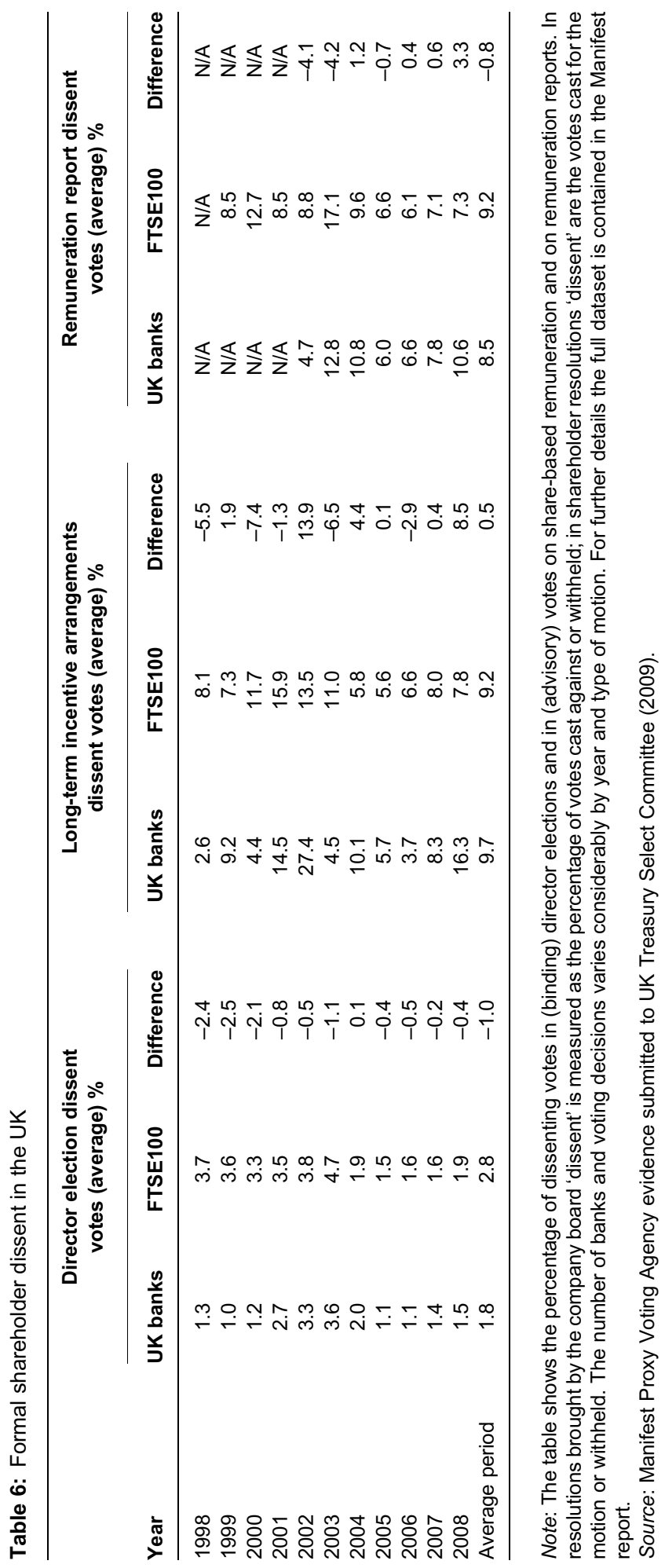


shareholders, given their embarrassment over the losses incurred, would have made these records public. We therefore conclude that institutional shareholders did not oppose risktaking at banks, but there is no direct evidence that they lobbied for it. What would have happened if bank boards had proposed pay packages linked to debt rather than to equity remains an open question.

Outside the United States banks are frequently controlled by blockholders. The blockholder is typically a family or the state and often appoints representatives to the board. The attitude to risk-taking by blockholders is ambiguous, as argued in section III. A widely cited pre-crisis study found that the presence of a 10 per cent + blockholder correlates with more risk-taking, as measured by Z-scores (Laeven and Levine, 2009). The finding would suggest that countries with blockholder-dominated banks should fare worse in the crisis. This was not the case. Among the countries associated with particularly stable banks (high Z-scores) during the 1996-2001 sample period were Ireland, the United Kingdom, and Switzerland, three countries with widely held banks that collapsed during the crisis (Laeven and Levine, 2009, Table A1). In contrast, many countries dominated by blockholder banks which had low Z-scores, such as Brazil, India, and Korea, withstood the crisis very well.

A more recent cross-country study by Gropp and Köhler (2010) includes the crisis period. They regress bank risk, measured by the deviation of return on equity in 2008 from its average in 2003-6, for a large number of listed and non-listed banks in OECD countries on various bank and country characteristics. They find a small positive effect of ownership concentration that is dominated by an 'anti-director-rights index' country dummy that correlates very strongly with ownership dispersion; the net effect suggests that losses were greater for widely held banks. The largest losses were incurred at (widely held) bank holding companies, but the losses at investment banks are reported as not significant. The latter result casts serious doubt on the accuracy of this dummy variable.

Government ownership of banks is controversial and a number of pre-crisis studies have argued that such ownership is associated with underdeveloped financial systems, instability, and low growth. ${ }^{6}$ Again, the crisis has contradicted this evidence, but not completely. In the OECD as a whole, losses at state-controlled banks were insignificant (Gropp and Köhler, 2010). But as we discussed in the board section (IV(i)), losses were concentrated in state banks in Belgium, Germany, and Spain.

Theory predicts that 'ownerless banks', such as mutual or cooperative banks that are 'owned' by depositors, take fewer risks than corporate banks. This proposition found some support in the US S\&L crisis. Corporate savings banks took greater risks than savings banks that were organized as mutual companies. Casual inspection of the list of failed institutions in 2008 (Tables 1-3) indicates that with the exception of the Cajas in Spain, one UK case, and two Irish cases, most failures occurred at corporate banks. Gropp and Köhler (2010) report that cooperative and mutual banks suffered small, and savings banks much larger, losses.

In summary, the empirical evidence on the role of institutional shareholders and blockholders is suggestive but not conclusive; in some cases, the results appear dubious. As for the studies on board independence, crude cross-country regressions are unlikely to provide reliable answers.

\footnotetext{
${ }^{6}$ A related pre-crisis literature links bank ownership to lending, for example Sapienza (2004). We do not review these findings here.
} 


\section{(iii) Pay for performance}

The leading theory of executive compensation has been formalized most completely by Holmström and Tirole (1993). Their setting is a widely held corporation with weak shareholders who want to align the CEO's long-run objectives with their own. The model shows that this can be achieved by rewarding CEOs with stock-based compensation. Jensen and Murphy (1990) suggested that the sensitivity of CEO pay to share price performance in the United States was too low in the 1980s. On average, CEOs only received $\$ 3.25$ for a $\$ 1,000$ change in shareholder value.

The idea of aligning CEO pay more closely with stockholder objectives by rewarding them with stock is the one fundamental foundation behind executive compensation practice today. The theory is that it makes sense to focus on stock-based compensation because under the efficient markets hypothesis the stock price is an unbiased estimate of the fundamental value of the firm. Hence, by making CEO compensation sensitive to the stock price, shareholders induce managers to focus on long-term value. The stock price itself becomes a measure of CEO performance.

Fahlenbrach and Stulz (2011) look at the performance of a sample of about 95 bank holding companies and investment banks, from 2006 going forward through the crisis. In particular, they measure performance by buy-and-hold returns from 1 July 2007 to 31 December 2008. This performance measure is regressed on five different measures of CEO incentives: cash bonus and salary, dollar ownership, dollar equity risk sensitivity, percentage ownership, and percentage risk sensitivity. If we think that inappropriate compensation is one of the causes of the crisis, then we would expect to see that those bank CEOs whose incentives were less well-aligned with shareholders, would have bigger losses. So one would expect to see that the lower, say, the CEO's dollar ownership in a bank, the worse its performance.

In a key regression of the paper, however, Fahlenbrach and Stulz find the opposite: just focusing on dollar ownership, the coefficient obtained is significantly negative. This means that the more a bank CEO held in stock, the worse the performance of the bank going forward. They repeat the regression adding some controls, such as stock return level for 2006, book-to-market, log market value, and so on, but the coefficient remains negative. This leads Fahlenbrach and Stulz to conclude that based on their analysis, there is no evidence that CEO incentive misalignment caused worse performance. If anything, it is the opposite: it is greater alignment that caused worse performance.

The second aspect of short-term risk incentives that Fahlenbrach and Stulz focus on is that if managers were mismanaging the bank, they would obviously have known. They would have seen trouble coming and they would have, at the very least, tried to sell their stock, so as not to incur any losses. Their conclusions are, in that context, rather surprising. When they look at insider trading, reported trading of stock by bank CEOs, in their sample, threequarters of the CEOs did not sell any shares at all. So we might conclude they did not see any trouble coming, or at least they thought they were running their bank appropriately and they did not need to sell their stock. They estimate that, on average, the CEOs actually lost close to $\$ 30 \mathrm{~m}$ on this buy-and-hold strategy, a substantial amount.

Regarding the losses of the CEOs in the crisis, a somewhat different perspective is taken by Bebchuck et al. (2009). They look at Bear Stearns and Lehman Brothers and how much the top executives made in total (Table 7). They come up with some really striking numbers: the top five executives at Bear Stearns and Lehman Brothers made between $\$ 1.4$ billion and $\$ 1$ billion cumulatively in cash bonuses and equity sales before their firm's collapse.

What is really striking about these numbers, in our view, is that Bear Stearns is a firm that is about ten times smaller than Lehman, and yet its management walked away with much 


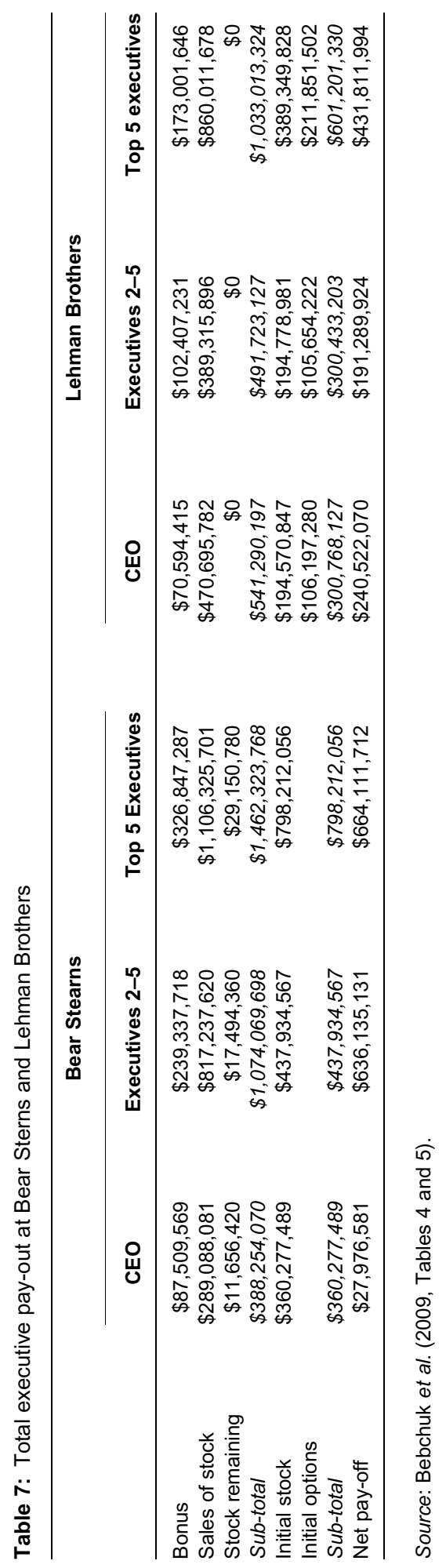


more in terms of compensation. Bebchuck et al. conclude that performance-based compensation at Bear Stearns and Lehman clearly did not align executive interests with long-term shareholder value. When the stock options vest there is an opportunity to sell the stock and this is what gives rise to short-term incentives. The executives are induced to pay attention to ensuring that they can sell at a good price when the options vest, rather than to preserving the stock's value in the long term.

The most compelling study of the link between compensation structures in the financial services industry and risk-taking is by Cheng et al. (2010). Did compensation structures in the financial industry create incentives towards excess risk-taking? To address this question the authors study how residual executive compensation in the US financial industry (that is, the compensation that cannot be explained by firm size and by industry factors) is related to measures of risk taken by the firm (as perceived by the market), and to performance (see Figure 2). The authors find striking evidence of a positive correlation between the level of residual pay and the firm's beta and other measures of risk. This finding is consistent with the hypothesis that executives were rewarded or encouraged to take excessive risks. The authors also find evidence that the executives who received the highest remuneration in the years leading up to the crisis were those in firms that performed the worst in the crisis. Chesney et al. (2010) confirm these findings by documenting a link between risk-taking incentives, independent boards, and write-downs during the crisis. Finally, Tung and Wang (2011) show that high ratios of deferred compensation and pension payments to equity correlate with less risk-taking.

\section{(iv) Internal controls}

Financial institutions are in the business of managing risk and one would therefore expect that the risk-control function is central to the corporate governance of such organizations. But as we learnt during the financial crisis and the hearings that were conducted in its aftermath, risk control proved to be inadequate in many cases.

Ellul and Yerramilli (2010) formally investigate the potential link between risk control, risk-taking, and losses incurred at the largest listed US bank holding companies (BHCs) (see Figure 3). To measure the strength of risk management inside a BHC they construct three 'risk management indices' (RMIs) that capture various combinations of ten observable characteristics of the risk management function: Does the bank have a Chief Risk Officer (CRO)? Is the CRO a senior executive? Is the CRO among the highest paid five executives? What is the ratio of CRO to CEO pay? Do the outside directors on the risk committee have banking experience? How often does the risk committee meet? Is the meeting frequency above average? What is the percentage of outside directors with banking experience? Is the proportion above average? Does the relevant risk committee report directly to the board, and not just to the CEO?

There is a surprising degree of variation among the 70 largest listed BHCs in the United States. In only just over half the cases, the risk committee reported directly to the board or the CRO was a senior executive. Only one out of five CROs was among the highest paid executives. Three-quarters of CROs were paid less than 36 per cent of CEO pay. Ellul and Yerramilli (2010) find that the last measure, labelled 'CRO centrality' is the dominant component when they related the RMI index to risk-taking.

Banks with more risk controls before 2006 took fewer risks and suffered fewer losses during the crisis. The results also hold from year-to-year over the whole period $2000-8$. They are robust to a number of control variables, such as BHC size, CEO pay-to-performance 
Figure 2: Residual compensation and risk-taking
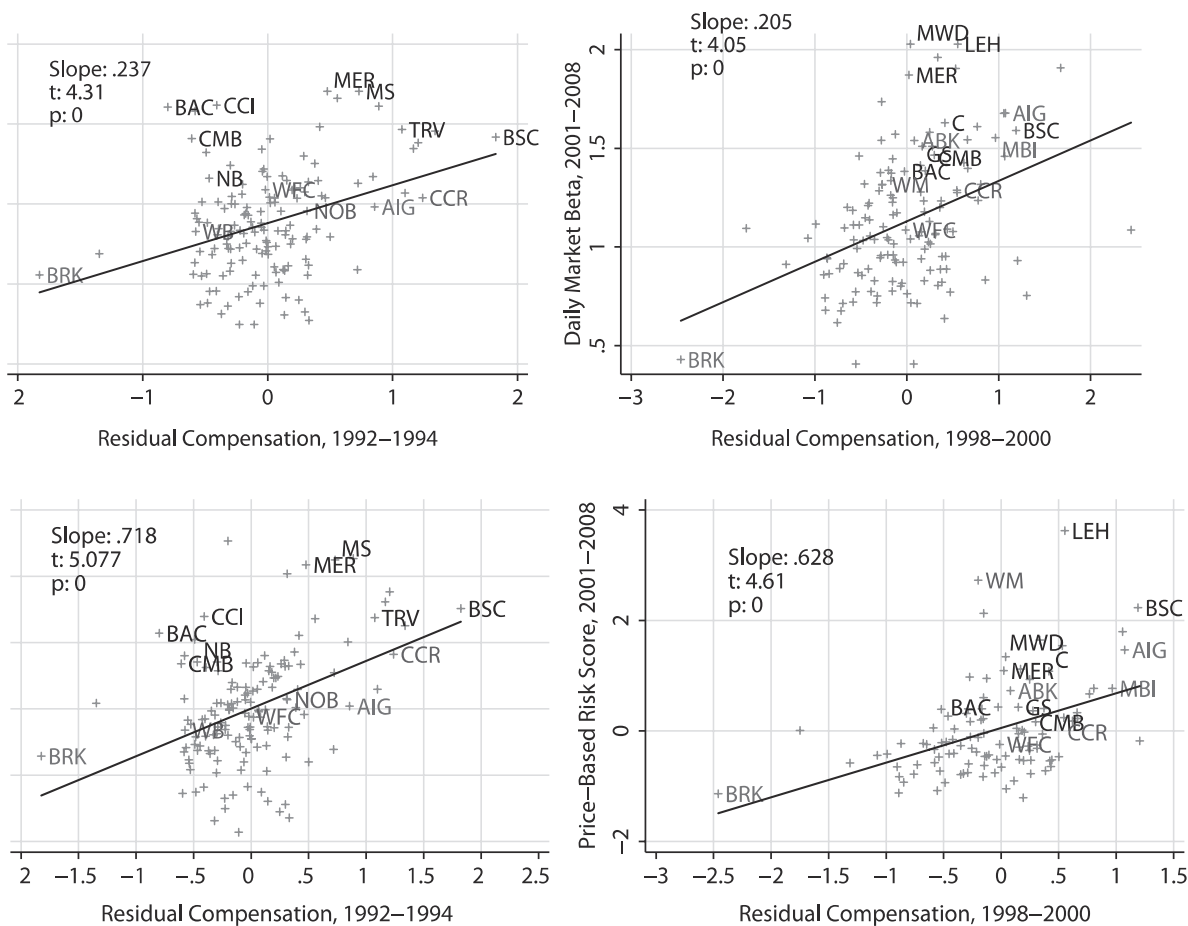

Source: Cheng et al. (2010).

sensitivity, institutional ownership, and the absence of takeover defences. This carefully conducted empirical study confirms the anecdotal evidence that emerges from reports and hearings on individual banks, on the low priority of risk management being a major cause of failure in 2008.

Case study evidence points in the same direction. The Valukas (2010) report on the Lehman bankruptcy states that senior management 'disregarded its risk managers, its risk policies, and its risk limits' (Vol. 1, p. 46). In 2007 the press reported that Lehman removed its CRO and the head of its fixed income division 'because of their opposition to management's growing accumulation of risky and illiquid investments'. In the UK a parliamentary investigation into the failure of HBOS alleged that its risk officer was made redundant for raising questions about the level and types of risk the bank was taking on. The former Chairman under examination declined to comment (BBC News, 2009). The casestudy evidence leaves little doubt that failures in internal risk management were a major contributor to bank failures.

\section{Reform proposals}

The OECD Principles of Corporate Governance (1999) are the standard reference for policymakers in developed economies. The publication of the Principles was triggered by the 1996 
Figure 3: Pre-crisis strength of risk management versus downside risk during the crisis

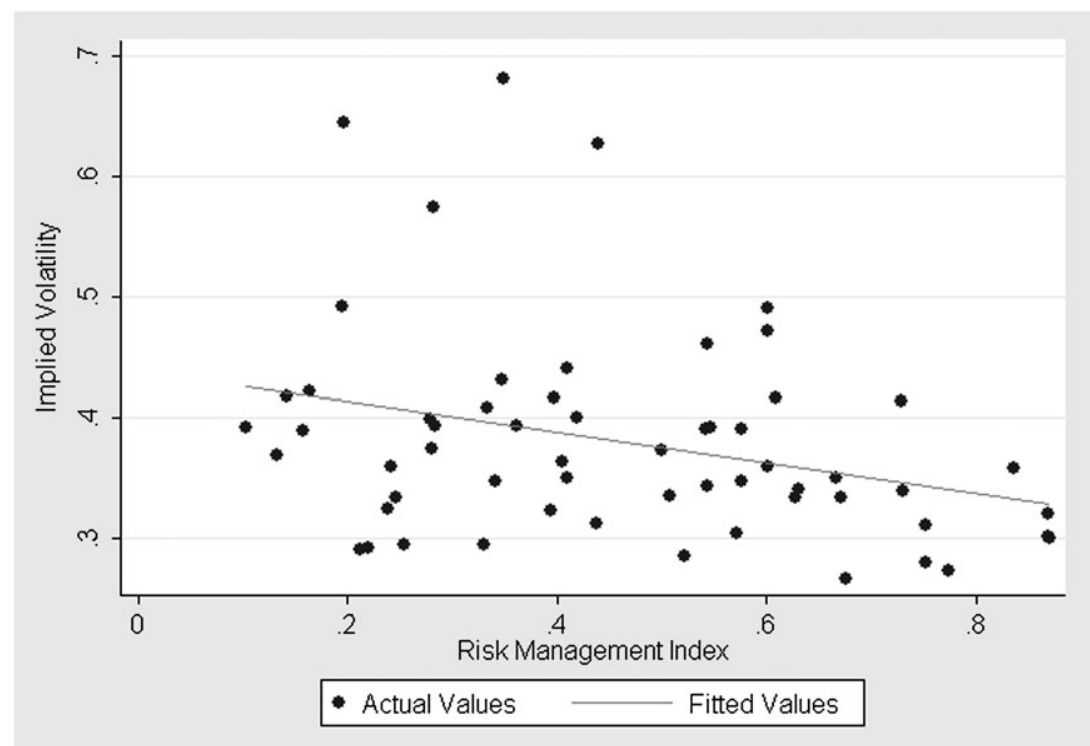

Notes: The figure plots the average downside risk of each BHC over the crisis years (2007 and 2008) versus its corresponding pre-crisis risk management index (RMI), which is defined as the average RMI of the BHC over the period 2003-6. The solid straight line in the figure is a plot of predicted values obtained for a regression of downside risk versus a constant and the pre-crisis RMI.

Source: Ellul and Yerramilli (2010).

Russia/Asia/Brazil crisis and they are one of the 12 key standards for sound financial systems adopted by the FSB. A revised version was published in 2004 to take into account the lessons from the 2001/2 Enron/Worldcom bankruptcies in the United States and the 2003 Parmalat scandal in Europe, failures which also gave rise to the Sarbanes-Oxley Act of 2002 and a European Commission corporate governance action plan. Recently the OECD (2010) has put out a note on the implementation of its principles based on the experience of the financial crisis.

In parallel the Basel Committee on Banking Supervisors formulated specific recommendations for bank governance. The first Basel Principles were published in 1999 and significantly updated in 2006. In both cases the Committee sought to complement the OECD Principles with what were believed to be specific governance requirements of banks. The Basel Committee also published a separate framework for internal control. In the previous sections we discussed why these principles, frameworks, and recommendations fell short: the 1999 version put too much emphasis on shareholders; the 2006 revision recognized the need to protect depositors and other creditors but came too late; and well established principles, such as those on internal control, were not sufficiently applied. The Basel Committee incorporated lessons from the crisis in a further update of the Principles (Basel Committee, 2010).

Reforming remuneration in banks is such a political priority that both the G20 governments and the FSB treat the subject. The FSB published Principles for Sound Compensation Practices and Implementation Standards in 2009. The FSB also conducted a peer review of 
the implementation of the standards. The Basel Committee has been charged with developing an assessment methodology for prudential supervisors and to analyse the remuneration practices banks have put in place. The overarching theme is 'risk-adjusted remuneration'.

In parallel, the United States, the European Commission, and individual states conducted their own reviews of local bank failures and put forward laws and/or recommendations. These include the Dodd-Frank bill in the United States, the Walker Recommendations (2010) in the United Kingdom, and the European Commission's Green Paper on the Corporate Governance of Financial Institutions (2010). Separate rules have been put in place for banks that received direct investment or aid from the relevant governments. We concentrate our discussion on the Basel Principles (2010) and the FSB (2009) remuneration standards, the main international reference documents.

The Basel Principles (2010) now state that bank governance is different: 'from a banking perspective, corporate governance involves the allocation of authority and responsibilities ... including how they ... protect the interests of depositors, meet shareholder obligations, and take into account the interests of other recognized stakeholders [supervisors, governments, bond holders]' (p. 5). The Principles seek to protect these interests by broadening the duty of the board ('the board should take into account the legitimate interests of shareholders, depositors and other relevant stakeholders'; p. 8) and assigning supervisors the role of monitors with the power to seek remedial action. The board is strengthened through the appointment of more competent directors and by reinforcing the risk-management function, including an upgrade of the CRO. The Principles are consistent with theory and the empirical evidence, but they do not break with pre-crisis tradition: 'the primary responsibility for good corporate governance rests with boards (supported by the control functions) and with senior management of banks' (p. 33). Shareholders continue to appoint and remove the management or supervisory boards. ${ }^{7}$ Will these boards really serve the interests of non-shareholder constituencies?

Remuneration policy reform is also in line with theory and the empirical evidence. The standards insist that remuneration in banks must be adjusted for risk. ${ }^{8}$ The main difficulty is implementation. The Basel Committee (2011) analysis of remuneration methodologies applied by banks post-crisis illustrates the challenge. What is the appropriate performance benchmark? Banks are considering a range of internal and external, relative and absolute, quantitative and qualitative measures. What is the appropriate risk-adjustment method? Many banks distinguish between quantitative and qualitative ex ante and ex post risk adjustment. Ex ante adjustments take into account the risk of future adverse outcomes. Ex post adjustments refer to observed outcomes. This can include 'malus clauses' to withhold all or part of deferred remuneration, or 'clawbacks' that claim back awards. How is the remuneration policy governed? Risk management and remuneration must be closely integrated and anchored appropriately at board level.

Numerous issues remain unsolved. In particular, the incentives of senior management continue to be aligned more closely with shareholders than with other constituencies, in particular depositors and other creditors. The Basel Committee (2010) analysis indicates that shareholder returns remain a widely used performance benchmark. Vesting periods remain short (typically 3 years) and 'long term' risk-adjusted incentives continue to be awarded as

\footnotetext{
${ }^{7}$ Board members appointed by controlling shareholders 'should have responsibilities to the bank itself, regardless who appoints them' (p. 15).

${ }^{8}$ The standards also recommend taking into account a broad range of risk, in particular credit, market, liquidity, operational, business legal, and reputational risk. Liquidity risk had been vastly underestimated before the crisis.
} 
equity. The administration of deferral and adjustment schemes is time-consuming and costly. There are also complex tax and legal issues involved.

Complexity, opacity, and subjectivity in risk-adjustment is a major concern. Banks are being allowed to experiment with remuneration methodologies they believe are most suitable for their particular circumstances. This is appropriate in theory but puts a substantial assessment burden on supervisors. In the absence of full public disclosure, the heterogeneity of methods makes it almost impossible for interested outside parties, such as creditors, analysts, credit-rating agencies, or academic researchers to assess the validity of the methodologies employed. The increasing range of remuneration practices will also provide opportunities for abuse. The trade-off between simplicity and verifiability versus flexibility and complexity requires additional thought and study. ${ }^{9}$

\section{Vl. Conclusion}

Financial regulation and policy has started to recognize that bank governance is different. It is now accepted that boards must have responsibilities to creditors as well as shareholders. Remuneration must be adjusted for risk. Internal risk controls must be strengthened. These are positive developments supported by theory and the available evidence. The reforms do not go far enough, however. Creditors still do not have a formal role in the corporate governance of banks, such as a seat on the board. The remuneration of executives must be aligned more simply and directly with debt holders, for example through credit default swaps.

\section{Appendix 1: Risk shifting ('gambling for resurrection')}

Consider a bank whose assets include at least $\$ 10$ that is held in readily accessible liquid form, and suppose that there is a risky but value-destroying investment opportunity: the bank can sink $\$ 10$ into a risky project that yields $\$ 80$ with probability $1 / 10$, and $\$ 0$ with probability $9 / 10$. Thus the project has a negative expected net present value of $-\$ 2$, and it should never be adopted.

However, if the bank is in or near financial distress, the bank's management will undertake the project if it acts on behalf of its shareholders. To see this, suppose the bank has outstanding obligations to a variety of creditors (including depositors, bondholders, and other lenders) with a face value of $\$ 30$.

For illustrative purposes, suppose that the total value of the bank's assets (including the liquid assets) is $\$ 30$, so that if the risky project is not adopted, the equity is worthless and the creditors can just be repaid in full.

If the risky project is adopted, then in case of failure equity holders get nothing and creditors get the remaining $\$ 20$ of assets ( $\$ 30$ minus the $\$ 10$ invested). If the project

\footnotetext{
9 There are worrying parallels with capital adequacy regulation. Basel I was simple and rigid; it imposed additional costs on some banks but was difficult to game. Basel II was superior in theory, but banks and supervisors failed in developing, applying, and assessing the appropriate risk-weighting models, in some cases deliberately.
} 
succeeds, the bank will be worth $\$ 30-\$ 10+\$ 80=\$ 100$, the creditors can be repaid in full (\$30) and shareholders receive the residual value of $\$ 70$.

Thus if the project is undertaken, expected shareholder value is $0.1 \times \$ 70=\$ 7$ while creditors receive an expected value of $0.9 \times \$ 20+0.1 \times \$ 30=\$ 21$. So investing in the project increases shareholder value by $\$ 7$ (from $\$ 0$ to $\$ 7$ ) at the expense of creditors, who lose $\$ 9$ on average (from a certain repayment of $\$ 30$ to an expected $\$ 21$ ).

This exercise can be repeated for different initial levels of bank asset values, ranging from $\$ 10$ to $\$ 50$ in the table below. Shareholders benefit from risk shifting once the initial asset value drops below a threshold ( $\$ 38.78$ in this example) that is typically somewhat above the asset value (\$30) at which the firm becomes insolvent.

\begin{tabular}{|c|c|c|c|c|c|c|c|c|}
\hline \multirow[b]{2}{*}{$\begin{array}{l}\text { Initial total } \\
\text { value } \\
\text { of bank } \\
\text { assets (\$) }\end{array}$} & \multicolumn{2}{|c|}{ In absence of project } & \multicolumn{4}{|c|}{ With risky project } & \multicolumn{2}{|c|}{ Impact of project on } \\
\hline & $\begin{array}{c}\text { Shareholder } \\
\text { value (\$) }\end{array}$ & $\begin{array}{l}\text { Creditor } \\
\text { value (\$) }\end{array}$ & $\begin{array}{c}\text { Total value } \\
\text { if project } \\
\text { succeeds } \\
\text { (probability } \\
1 / 10)(\$)\end{array}$ & $\begin{array}{c}\text { Total value } \\
\text { if project fails } \\
\text { (probability } \\
9 / 10)(\$)\end{array}$ & $\begin{array}{c}\text { Expected } \\
\text { shareholder } \\
\text { value (\$) }\end{array}$ & $\begin{array}{l}\text { Expected } \\
\text { creditor } \\
\text { value (\$) }\end{array}$ & $\begin{array}{l}\text { Shareholder } \\
\text { value } \\
\text { (\$) }\end{array}$ & $\begin{array}{l}\text { Creditor } \\
\text { value } \\
\text { (\$) }\end{array}$ \\
\hline 50 & 20 & 30 & 120 & 40 & 18 & 30 & -2 & 0 \\
\hline 40 & 10 & 30 & 110 & 30 & 8 & 30 & -2 & 0 \\
\hline 35 & 5 & 30 & 105 & 25 & 7.5 & 25.5 & 2.5 & -4.5 \\
\hline 30 & 0 & 30 & 100 & 20 & 7 & 21 & 7 & -9 \\
\hline 20 & 0 & 20 & 90 & 10 & 6 & 12 & 6 & -8 \\
\hline 10 & 0 & 10 & 80 & 0 & 5 & 3 & 5 & -7 \\
\hline
\end{tabular}

To the extent that the creditors are depositors, the deposit insurer would have to cover the losses. It would want to step in to stop the risky investment project and prevent such a drain on its resources.

\section{Appendix 2: Stockholder-creditor conflicts: debt overhang}

To illustrate the deterrents to raising new capital, consider a situation where a bank or firm is exposed to a simple two-state risk: with probability $4 / 5$ its assets are worth $€ 120$, while with probability $1 / 5$ its assets turn sour and are worth only $€ 60$. Suppose that it has an attractive risk-free opportunity: if it can raise a further $€ 36$ to invest in a project, its total value will increase by $€ 40$ regardless of the situation it finds itself in. The project's NPV is thus $€ 40-$ $€ 36=€ 4$, so clearly the money ought to be raised and the investment made:

\begin{tabular}{lccc}
\hline \multicolumn{1}{c}{ Overall firm value } & Bad state (probability 1/5) & Good state (probability 4/5) & Expected value \\
\hline Without new capital & $€ 60$ & $€ 120$ & $€ 108$ \\
With new capital of $€ 36$ & $€ 100$ & $€ 160$ & $€ 148$ \\
\hline
\end{tabular}

However, because the benefits flow disproportionately towards making the creditors whole, the bank may be unwilling or unable to raise the capital and invest in the project. Depending on how indebted the bank is, there are three possible regimes. 


\section{(i) Low debt: the investment is made}

If the pre-existing senior debt is low enough (€80 or below in this example), the management, acting in the interests of the shareholders, will wish to raise the $€ 36$ of new capital and invest, because the NPV of the projects exceeds the associated transfer of value to creditors. For example, if the face value of the debt is $€ 70$, the expected value of the existing equity increases with new capital: ${ }^{10}$

\begin{tabular}{lccc}
\hline & Bad state (probability 1/5) & Good state (probability 4/5) & Expected value \\
\hline Without new capital & & & \\
Debt & $€ 60$ & $€ 70$ & $€ 68$ \\
Equity & $€ 0$ & $€ 50$ & $€ 40$ \\
With new capital & $€ 70$ & $€ 70$ & $€ 70$ \\
Debt & $€ 30$ & $€ 37.5$ & $€ 36$ \\
New investors & $€ 0$ & $€ 52.5$ & $€ 42$ \\
Equity & &
\end{tabular}

\section{(ii) High debt: the firm can invest but does not wish to}

If the face value of the senior debt exceeds a threshold value (in casu $€ 80$ ), the gain to the existing creditors exceeds the NPV of the project and management will not want to raise capital because shareholders lose on average. For example, if the face value of the debt is $€ 100$ :

\begin{tabular}{lrrr}
\hline & Bad state (probability 1/5) & Good state (probability 4/5) & Expected value \\
\hline Without new capital & & & \\
Debt & $€ 60$ & $€ 100$ & $€ 92$ \\
Equity & $€ 0$ & $€ 20$ & $€ 16$ \\
With new capital & $€ 100$ & $€ 100$ & $€ 100$ \\
Debt & $€ 0$ & $€ 45$ & $€ 36$ \\
New investors & $€ 0$ & $€ 10$ & $€ 12$ \\
Equity & &
\end{tabular}

\section{(iii) Prohibitively high debt: the firm cannot raise the capital}

If the face value of the existing senior debt exceeds a further threshold (€115 in the example), there is not enough value in the good state to reward new investors for their capital

\footnotetext{
${ }^{10}$ The tables are constructed as follows. First, a debt repayment equal to its face value or the total firm value, whichever is smaller, goes to the existing debt holders in each state. New investors receive the smaller of $€ 36$ or what is left of the firm's total value after paying existing debt holders in the bad state; in the good state they receive whatever amount is needed to induce them to put up money (i.e. to attain an expected value of $€ 36$ ). Any money remaining in each state goes to the equity holders, who wish to maximize the expected value of these pay-offs.
} 
injection: they need to receive at least $€ 45$ so that their expected pay-off compensates them for the $€ 36$ that they invest. The bank is neither willing nor able to raise new capital.

\section{References}

Basel Committee (1999), Enhancing Corporate Governance for Banking Organisations, Switzerland, Basel Committee on Banking Supervision.

- (2006), Enhancing Corporate Governance for Banking Organisations, Switzerland, Basel Committee on Banking Supervision.

- (2010), Principles for Enhancing Corporate Governance, Switzerland, Basel Committee on Banking Supervision.

- (2011), Range of Methodologies for Risk and Performance Alignment of Remuneration, Switzerland, Basel Committee on Banking Supervision.

BBC News (2009), 'Former Banking Bosses Say "'Sorry", http://news.bbc.co.uk/go/pr/fr/-/2/hi/business/ 7880292.stm

Bebchuk, L. A., Cohen, A., and Spamann, H. (2009), 'The Wages of Failure: Executive Compensation at Bear Stearns and Lehman 2000-2008', ECGI-Finance Working Paper No. 287, available at SSRN, http://ssrn.com/abstract $=1513522$

Becht, M., Bolton, P., and Röell, A. A. (2007), 'Corporate Law and Governance', in A. M. Polinsky, and S. Shavell (eds), Handbook of Law and Economics, North-Holland Elsevier.

- Franks, J., and Grant, J. (2011), 'Unfulfilled Expectations? The Returns to International Hedge Fund Activism', European Corporate Governance Institute, Brussels, mimeo.

- - Mayer, C., and Rossi, S. (2008), 'Returns to Shareholder Activism: Evidence from a Clinical Study of the Hermes UK Focus Fund', ECGI-Finance Working Paper No. 138/2006; London Business School Finance Working Paper No. FIN462, available at SSRN, http://ssrn.com/abstract $=934712$

Beltratti, A., and Stulz, R. M. (2010), 'The Credit Crisis Around the Globe: Why Did Some Banks Perform Better?', Charles A. Dice Center Working Paper No. 2010-5; Fisher College of Business Working Paper No. 2010-03-005, available at SSRN, http://ssrn.com/abstract $=1572407$

Bolton, P., Mehran, H., and Shapiro, J. D. (2010), 'Executive Compensation and Risk Taking', FRB of New York Staff Report No. 456, available at SSRN, http://ssrn.com/abstract=1635349

- Scheinkman, J. A., and Xiong, W. (2006), 'Pay for Short-term Performance: Executive Compensation in Speculative Markets', Review of Economic Studies, 73, 577-610.

Brav, A., Jiang, W., and Kim, H. (2009), 'Hedge Fund Activism: A Review', Foundations and Trends in Finance, Now Publishers.

Cheng, I., Hong, H. G., and Scheinkman, J. A. (2010), 'Yesterday's Heroes: Compensation and Creative Risk-Taking', ECGI-Finance Working Paper No. 285/2010, available at SSRN, http://ssrn.com/ abstract $=1502762$

Chesney, M., Stromberg, J., and Wagner, A. F. (2010), 'Risk-taking Incentives, Governance, and Losses in the Financial Crisis', Swiss Finance Institute Research Paper No. 10-18, available at SSRN: http:// ssrn.com/abstract $=1595343$

Cunat, V., and Garicano, L. (2010), 'Did Good Cajas Extend Bad Loans? Governance, Human Capital and Loan Portfolios', forthcoming in S. Bentolila, M. Boldrin, J. Díaz Jiménez, and J. J. Dolado (eds), The Crisis of the Spanish Economy.

Diamond, D. W., and Dybvig, P. H. (1983), 'Bank Runs, Deposit Insurance, and Liquidity', Journal of Political Economy, 91(3), 401-19.

Ellul, A., and Yerramilli, V. (2010), 'Stronger Risk Controls, Lower Risk: Evidence from US Bank Holding Companies', AFA 2011 Denver Meetings Paper, available at SSRN: http://ssrn.com/abstract=1550361

Erkens, D., Hung, M., and Matos, P. P. (2010), 'Corporate Governance in the 2007-2008 Financial Crisis: Evidence from Financial Institutions Worldwide', ECGI-Finance Working Paper No. 249/2009, available at SSRN: http://ssrn.com/abstract=1397685

Fahlenbrach, R., and Stulz, R. M. (2011), 'Bank CEO Incentives and the Credit Crisis', Journal of Financial Economics, 99(1), 11-26. 
Fernandes, N., and Fich, E. (2009), 'Does Financial Experience Help Banks during Credit Crises?', unpublished working paper, IMD-Lausanne, Switzerland.

Ferreira, D., Kirchmaier, T., and Metzger, D. (2010), 'Boards of Banks', ECGI-Finance Working Paper No. 289/2010, available at SSRN: http://ssrn.com/abstract $=1620551$

Financial Stability Board (2009), 'Principles for Sound Compensation Practices', Washington DC.

Gropp, R., and Köhler, M. (2010), 'Bank Owners or Bank Managers: Who is Keen on Risk? Evidence from the Financial Crisis', ZEW Discussion Paper No. 10-013, Mannheim.

Holmström, B., and Tirole, J. (1993), 'Market Liquidity and Performance Monitoring', Journal of Political Economy, 101(4), 678-709.

Hau, H., and Thum, M. P. (2009), 'Subprime Crisis and Board (In-)Competence: Private vs Public Banks in Germany', CESifo Working Paper Series No. 2640, available at SSRN: http://ssrn.com/ abstract $=1360698$

Jensen, M. C., and Murphy, K. J. (1990), 'Performance Pay and Top Management Incentives', Journal of Political Economy, 98(2), 225-64.

Karpoff, J. M. (2001), 'The Impact of Shareholder Activism on Target Companies: A Survey of Empirical Findings', working paper, University of Washington.

Laeven, L., and Levine, R. (2009), 'Bank Governance, Regulation and Risk Taking', Journal of Financial Economics, 93(2), 259-75.

Landier, A., Sraer, D., and Thesmar, D. (2010), 'Going for Broke: New Century Financial Corporation, 20042006', available at SSRN: http://ssrn.com/abstract=1697823

Lewis, M. (2010), The Big Short: Inside the Doomsday Machine, W.W. Norton \& Company

- (2011), 'It's the Economy, Dummkopf!', Vanity Fair, September.

Mehran, H., Morrison, A. D., and Shapiro, J. D. (2011), 'Corporate Governance and Banks: What Have We Learned from the Financial Crisis?', FRB of New York Staff Report No. 502, available at SSRN: http:// ssrn.com/abstract $=1880009$

Minton, B. A., Taillard, J., and Williamson, R. G. (2010), 'Do Independence and Financial Expertise of the Board Matter for Risk Taking and Performance?', Charles A. Dice Center Working Paper No. 2010-14, available at SSRN: http://ssrn.com/abstract $=1661855$

Missal, M. J. (2008), New Century TRS Holdings Inc, Final Examiner Report, US Bankruptcy Court for the District Delaware, Case No. 07-10416 (KJC), available at http://pdfserver.amlaw.com/ca/newcentury01_ 0327.pdf

Morgenson, G., and Rosner, J. (2011), Reckless Endangerment: How Outsized Ambition, Greed, and Corruption Led to Economic Armageddon, Times Books.

OECD (2010), 'Corporate Governance and the Financial Crisis: Conclusions and Emerging Good Practices to Enhance Implementation of the Principles', available at: http://www.oecd.org/dataoecd/53/62/ 44679170.pdf

Ross Sorkin, A. (2009), Too Big to Fail: The Inside Story of How Wall Street and Washington Fought to Save the Financial System - and Themselves, Viking Adult.

Sapienza, P. (2004), 'The Effects of Government Ownership on Bank Lending', Journal of Financial Economics, 72(2), 357-84.

Tung, F., and Wang, X. (2011), 'Bank CEOs, Inside Debt Compensation, and the Global Financial Crisis', 5th Annual Conference on Empirical Legal Studies Paper; Boston University School of Law Working Paper, forthcoming, available at SSRN: http://ssrn.com/abstract=1570161

Valukas, A. R. (2010), Lehman Brothers Holdings Inc. Chapter 11 Proceedings Examiner's Report, available at http://lehmanreport.jenner.com 